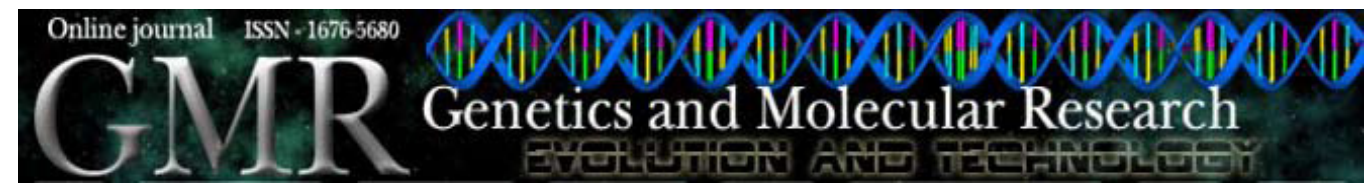

Short Communication

\title{
Absence of the exon 1 coding sequence of the androgen receptor gene associated with teratozoospermia in a Brazilian population
}

\author{
W.E.J.C. Mesquita ${ }^{1,2,3}$, M.S. Approbato ${ }^{4}$, K.K.V.O. Moura ${ }^{2,5}$ and \\ R.S.A. Jesuíno ${ }^{3,6}$ \\ ${ }^{1}$ Departamento de Biologia, Universidade Católica de Goiás, Goiânia, GO, Brasil \\ ${ }^{2}$ Núcleo de Pesquisas Replicon, Universidade Católica de Goiás, Goiânia, GO, Brasil \\ ${ }^{3}$ Laboratório de Biotecnologia de Fungos, \\ Universidade Federal de Goiás, Goiânia, GO, Brasil \\ ${ }^{4}$ Hospital das Clínicas, Universidade Federal de Goiás, Goiânia, GO, Brasil \\ ${ }^{5}$ Departamento de Biomedicina, \\ Universidade Católica de Goiás, Goiânia, GO, Brasil \\ ${ }^{6}$ Instituto de Ciências Biológicas, Universidade Federal de Goiás, Goiânia, GO, Brasil \\ Corresponding author: W.E.J.C. Mesquita \\ E-mail: wyara_castro@yahoo.com.br
}

Genet. Mol. Res. 8 (4): 1423-1426 (2009)

Received September 10, 2009

Accepted September 28, 2009

Published November 24, 2009

ABSTRACT. The androgen receptor (AR) is a protein encoded by the $A R$ gene, which when mutated may affect spermatogenesis, the process in which spermatozoa are produced; thus, $A R$ mutations could lead to male infertility. We examined exon 1 of the $A R$ gene in men with idiopathic infertility. Blood or semen samples from 111 infertile, oligozoospermic $(\mathrm{N}=31)$, asthenozoospermic $(\mathrm{N}=23)$, teratozoospermic $(\mathrm{N}=33)$, and azoospermic $(\mathrm{N}=24)$ men were analyzed. The extracted DNA was amplified for the exon 1 region of the $A R$ gene. There was a significant correlation between the absence of exon 1 in the $A R$ gene and spermatogenesis defects $(\mathrm{P}=$ $0.015)$. This association was significant in teratozoospermic men (51.5\% of the sample). We found that lack of amplification of exon 
1 of the $A R$ gene by polymerase chain reaction is associated with morphological defects in the spermogram.

Key words: Androgen receptor; $A R$ gene; Male infertility; Spermatogenesis; Teratozoospermia

\section{INTRODUCTION}

Male infertility is associated with 55\% of conjugal infertility cases, and is the only form of infertility in $35 \%$ of all cases (Bordin et al., 2005). It is estimated that worldwide more than 70 million couples are infertile, most of which are in developing countries (Ombelet et al., 2008). Male infertility is characterized by the inability to produce sperm with normal count, morphology or motility, or a combination of these factors (de Kretser, 1997; Vogt, 2004; Angelopoulou et al., 2007). Spermatogenesis, the process of sperm production, depends on high levels of male sex hormones, the androgens (Kang et al., 2003), which must be associated with the androgen receptor (AR) to trigger the respective cell events. AR has the capacity to induce gene expression and to promote the development of the cell cycle (Yong et al., 2003).

AR is a ligand-activated regulatory transcription protein of the superfamily of nuclear receptors, and is encoded by the $A R$ gene (Ghadessy et al., 1999). The $A R$ gene has 8 exons that encode 3 main domains: i) the amino terminal domain or transactivation domain (TAD), which is encoded by exon 1; ii) the DNA binding domain, encoded by exons 2 and 3, and iii) the ligand binding domain (LBD), which is encoded by exons 4 to 8 (Yong et al., 2003; Mooney et al., 2003; Zhu, 2005; Singh et al., 2006). Specific mutations have been associated with male infertility, and have been identified mainly in the TAD and LBD domains (Vogt, 2004).

This short communication assessed the presence or absence of exon 1, which encodes TAD of AR, in men presenting idiopathic infertility. DNA samples extracted from blood or semen provided by men with infertility confirmed by spermogram were analyzed. The subjects were referred for clinical treatment of infertility in the Laboratory of Human Reproduction Studies, Hospital das Clínicas, Federal University of Goiás, Brazil. This study was approved by the National Committee for Ethics in Research, CONEP, under authorization number 11979.

\section{MATERIAL AND METHODS}

Thirty-one oligozoospermic individuals (who presented low sperm count), 23 asthenozoospermic individuals (showing spermatozoa with abnormal motility), 33 teratozoospermic men (with defective sperm morphology), and 24 azoospermic individuals (with no spermatozoa in ejaculate) were analyzed.

Samples of 95 normozoospermic individuals were used as control. Patients presenting syndromes or mutations in the AZF region of chromosome $\mathrm{Y}$ were excluded. All patients signed a written consent form. The DNA samples used were extracted from semen and/or blood of 206 patients using the Illustra Blood Genomic Prep kit (GE Healthcare, USA). The region corresponding to exon 1 of the $A R$ gene was amplified by polymerase chain reaction (PCR) (Mesquita, 2009). The results obtained were analyzed by logistic regression using the SPSS 15.0 software. Significance levels were defined as $\alpha<0.05$. 


\section{RESULTS}

Mean subject age was 34.58 years $(\mathrm{SD}=10.29$ years) for infertile patients and 34.47 years ( $\mathrm{SD}=7.74$ years) for normozoospermic subjects. No statistically significant difference was observed between ages $(\mathrm{P}<0.614)$.

The exon 1 region of the $A R$ gene was not amplified in 17 (51.5\%) of teratozoospermic subjects, in $3(13 \%)$ of asthenozoospermic subjects, in $3(9.7 \%)$ of oligozoospermic subjects, and in $6(25 \%)$ of azoospermic subjects. A significant correlation was observed between the absence of exon 1 and infertility as detected by the spermogram $(P=0.015)$. This significant correlation can be explained by the high frequency $(51.5 \%)$ of teratozoospermic subjects who did not amplify exon 1 of the $A R$ gene.

\section{DISCUSSION}

Teratozoospermia is characterized by morphological defects in spermatozoa and corresponds to less than $30 \%$ of the normal forms (OMS, 1994). Few studies have associated the mutation in the $A R$ gene with morphological changes detected in spermograms. In a study that analyzed the association between changes in exon 1 (concerning CAG polymorphism) and sperm defects in Arab and Jewish subjects showing abnormal sperm count, motility and morphology, Milatiner et al. (2004) reported a positive correlation only in teratozoospermic patients. The authors concluded that longer repeats of CAG polymorphism may cause defects in sperm morphology. Nevertheless, Giwercman et al. (2001) and Lund et al. (2003) reported a higher frequency of mutations in exon 1 of the $A R$ gene in patients with changes in sperm count, azoospermia and oligozoospermia. Yet, it is important to note that most studies on male infertility are conducted by the oligozoospermic and azoospermic subjects, possibly due to the fact that sperm defects are the most common causes of infertility (Ghadessy et al., 1999; Giwercman et al., 2001; Ferlin et al., 2006).

Most studies conducted on male infertility report the association of changes in sperm count with different genetic variables, such as microdeletion of chromosome Y, AZF and DAZ gene, and mutation and polymorphisms in nuclear receptors, AR and estrogen receptors (ER $\alpha$ and ER $\beta$ ) (Yong et al., 2003; Vogt, 2004; Fernandes et al., 2004; Gottlieb et al, 2005; Aschim et al., 2005).

The present study examined the occurrence or not of amplification of exon 1 of the gene that encodes AR in men presenting idiopathic infertility by PCR. However, it was as yet impossible, in this initial approach, to determine the likely mutations (whether point mutations, chromosome inversions or deletions) that may have stopped the annealing of nucleotides and the consequent non-amplification of exon 1 of the $A R$ gene. Further, more in-depth studies are required to identify the type of mutation in exon 1 . However, the results obtained in the present study are important because they provided the first description of a change in exon 1 of the $A R$ gene as a likely cause of male infertility in teratozoospermic men who live in the midwest region of Brazil. This study contributes to our knowledge of the relationship between genotype and phenotype (teratozoospermia), since current literature on the theme is rather scarce.

\section{ACKNOWLEDGMENTS}

This study was carried out in the Núcleo de Pesquisas Replicon, Universidade Católica de Goiás, in partnership with the Laboratório de Biotecnologia de Fungos, Universidade 
Federal de Goiás, with grants from the Universidade Católica de Goiás, GO, Brazil (UCG/ PROPE). W.E.J.C. Mesquita was supported by Coordenação de Aperfeiçoamento de Pessoal de Nível Superior (CAPES), which awarded grant.

\section{REFERENCES}

Angelopoulou R, Plastira K and Msaouel P (2007). Spermatozoal sensitive biomarkers to defective protaminosis and fragmented DNA. Reprod. Biol. Endocrinol. 5: 36.

Aschim EL, Giwercman A, Stahl O, Eberhard J, et al. (2005). The RsaI polymorphism in the estrogen receptor-b gene is associated with male infertility. J. Clin. Endocrinol. Metab. 90: 5343-5348.

Bordin BM, Arruda JT, Miranda LCB, Silva RCPC, et al. (2005). Alterações no Espermograma e a Associação com Tabagismo e Etilismo. In: Anais $32^{\circ}$ Congresso Brasileiro de Análises Clínicas e $5^{\circ}$ Congresso Brasileiro de Citologia Clínica, Goiânia, 54b.

de Kretser DM (1997). Male infertility. Lancet 349: 787-790.

Ferlin A, Vinanzi C, Garolla A, Selice R, et al. (2006). Male infertility and androgen receptor gene mutations: clinical features and identification of seven novel mutations. Clin. Endocrinol. 65: 606-610.

Fernandes S, Paracchini S, Meyer LH, Floridia G, et al. (2004). A large AZFc deletion removes DAZ3/DAZ4 and nearby genes from men in Y haplogroup N. Am. J. Hum. Genet. 74: 180-187.

Ghadessy FJ, Liow SL and Yong EL (1999). Mutations in the promoter region of the androgen receptor gene are not common in males with idiopathic infertility. Mol. Hum. Reprod. 5: 287-290.

Giwercman YL, Nikoshkov A, Bystrom B, Pousette A, et al. (2001). A novel mutation (N233K) in the transactivating domain and the N756S mutation in the ligand binding domain of the androgen receptor gene are associated with male infertility. Clin. Endocrinol. 54: 827-834.

Gottlieb B, Beitel LK and Trifiro MA (2005). Symposium: genetic aspects of male (in)fertility: Molecular pathology of the androgen receptor in male (in)fertility. Reprod. Biomed. Online 10: 42-48.

Kang HY, Tsai MY, Chang C and Huang KE (2003). Mechanisms and clinical relevance of androgens and androgen receptor actions. Chang Gung. Med. J. 26: 388-402.

Lund A, Juvonen V, Lahdetie J, Aittomaki K, et al. (2003). A novel sequence variation in the transactivation regulating domain of the androgen receptor in two infertile Finnish men. Fertil. Steri. 79 (Suppl 3): 1647-1648.

Mesquita WEJC (2009). Análise de Alterações no Gene Receptor de Andrógeno em Homens com Infertilidade Idiopática. Master's thesis, Universidade Federal de Goiás, Goiânia.

Milatiner D, Halle D, Huerta M, Margalioth EJ, et al. (2004). Associations between androgen receptor CAG repeat length and sperm morphology. Hum. Reprod. 19: 1426-1430.

Mooney SD, Klein TE, Altman RB, Trifiro MA, et al. (2003). A functional analysis of disease-associated mutations in the androgen receptor gene. Nucleic Acids Res. 31: e42.

Ombelet W, Cooke I, Dyer S, Serour G, et al. (2008). Infertility and the provision of infertility medical services in developing countries. Hum. Reprod. Update 14: 605-621.

Organização Mundial da Saúde (OMS) (1994). Manual de Laboratório para o Exame do Sêmen Humano e Interação Esperma-Muco Cervical. 1st edn. Editora Santos, São Paulo.

Singh R, Deepa SR, Madhavi S, Gupta NJ, et al. (2006). Male infertility: no evidence of involvement of androgen receptor gene among Indian men. J. Androl. 27: 102-105.

Vogt PH (2004). Molecular genetics of human male infertility: from genes to new therapeutic perspectives. Curr. Pharm. Des. 10: 471-500.

Yong EL, Loy CJ and Sim KS (2003). Androgen receptor gene and male infertility. Hum. Reprod. Update 9: 1-7.

Zhu YS (2005). Molecular basis of steroid action in the prostate. Cellscience 1: 27-55. 